protective covering for labels, it is found that in course of time dust accumulates between the card and the 'Perspex', and periodical removal and cleaning are a time-wasting process of little permanent value. A more satisfactory result is obtained by using 'Perspex' liquid cement containing chloroform to seal the label, and Mr. Kennedy gives practical details for doing this. The second use is for the reproduction of flint tools. It was found that 'Perspex' flakes in a similar fashion to flint when kept cold or, even better, when chilled. It is thus only necessary to use 'Perspex' of the correct colour, and by a combination of cutting out, filing, flaking and scraping an excellent imitation of a flint implement can be obtained.

\section{Technical Hardness Measurement: International Conference in Bremen}

An international conference on "Hardness Measurement in the Works" will be held in Bremen during September 22-23, in connexion with an exhibition there of modern hardness-measuring equipment of German and foreign manufacture. It is the second to be held in Bremen and is being arranged by the Arbeitsgemeinschaft für Fertigungstechnisches Messwesen (Working Committeo for Metrology in Production) and the Institut für Härteprüftechnik (Institute for Hardness-testing Technology). At the conference, representatives from Austria, France, Germany, Great Britain, Japan and the United States will discuss actual problems of hardness messurement according to Rockwell, low-load and mioro-hardness measurements after Vickers, hardness measurement on internal surfaces, as well as the possibilities and advantages of using technical statistios in the field of hardness testing. It is hoped to contribute to the establishment of internationally comparable hardness values, which are of much importance for technical products. Further details regarding the conference can be obtained from AFM, Verein Deutscher Ingenieure, Prinz Georg Strasse, Düsseldorf, Germany.

\section{Association of Universities of the British Common-} wealth

A Commonwealth Inter-University Conference will be held in Melbourne, Australia, during August 9-12, comprising the members of the Executive Council of the Association of Universities of the British Commonwealth, which holds an overseas meeting in the years between its quinquennial congresses. Similar meetings have recently been held in Canada (1949 and 1954), New Zealand (1950) and India (1951-52), but this is the first to be held in Australia. These conferences, which have been supported very generously by the Nuffield Foundation, provide the opportunity for discussion of matters of academic policy and Commonwealth inter-university relationships. The present meeting is to be presided over by Mr. A. P. Rowe, vico-chancellor of the University of Adelaide, and chairman this year of the Association of Universities of the British Commonwealth, and each Commonwealth country will be represented by one or more university executive heads, the United Kingdom party comprising Dr. R. S. Aitken (Birmingham), the Right Hon. H, U. Willink (Cambridge), Dr. D. W. Logan (London) and Mr. C. H. Wilson (University College, Leicester). The secretary of the conference is Dr. J. F. Foster, secretary of the Association of Universities of the British Commonwealth. The conference members while in Australia will visit other universitios there and will attend the inauguration ceremonies of the new University of New England at Armidale, New South Wales, on August 4.

\section{University of London}

THE title of professor emeritus in the University of London has been conferred on the following: Prof. J. H. Dible, on his retirement from the chair of pathology at the Postgraduate Medical School of London; Prof. Herbert Dingle, on his retirement from the chair of history and philosophy of science at University College; Prof. V. C. Illing, on his retirement from the professorship of geology (oil technology) at the Imperial College of Science and Technology ; Prof. H. H. Read, on his retirement from the chair of geology at the Imperial College of Science and Technology.

The title of reader in botany in the University of London has been conferred on Sir Nigel Ball, Bart., in respect of his post at King's College, and that of professor of physics in the University of London on Dr. W. C. Price, in respect of his post at King's College.

The following appointments in the University have been announced: Prof. J. Duchesne, director of the spectroscopic radio-electric laboratory in the University of Liège, to the visiting professorship of Belgian studies in the University of London for a period during the second and third terms of the session 1955-56; Dr. Geoffrey Wilkinson, assistant professor of chemistry at Harvard University, to the University chair of inorganic chemistry tenable at the Imperial College of Science and Technology; Dr. W. G. Overend, lecturer in chemistry in the University of Birmingham, to the University readership in organic chemistry tenable at Birkbeck College; Dr. W. S. Pitcher, lecturer at the Imperial College of Science and Technology, to tho University readership in geology tenable at King's College.

\section{University of Leeds}

THe following appointments in the University of Leeds have been announced: Mr. D. C. Johnson, to be professor of mechanical engineering from January 1 , 1956 ; Dr. D. Bradley, to be lecturer in mechanical engineering; Dr. D. A. Jones, to be lecturer in electrical engineering; Mr. S. C. Mitchell, to be lecturer in fuel technology; Dr. J. H. Robertson, Brotherton lecturer in the Department of Inorganic and Structural Chemistry, to be lecturer in the Department of Inorganic and Structural Chemistry; Mr. T. Wilson, to be lecturer in electrical engineering.

The University has acknowledged the following gifts, among others: $£ 300$ from the Yorkshire Agricultural Society, for the Department of Agriculture; $£ 700$ from Messrs. Joseph Booth and Brothers, Rodley, for the Department of Civil Engineering, to maintain a student for two years to undertake research work on the dynamic stresses induced in cranes ; $£ 3,000$ for 1954-55 from the North-Eastern Division of the National Coal Board, for the Department of Mining; $£ 940$ from the Royal Society, for the Department of Physics, for research carried out by Dr. R. S. Tebble on the magnetic properties of metals and alloys at high temperatures.

\section{Salters' Institute of Industrial Chemistry: Awards}

THE Salters' Company has elected M. J. Stephen to be a Salters' Fellow for the year 1955-56. Mr. Stephen, who is a graduate of the University of the 